\title{
Power and inaction: why organizations fail to address workplace bullying
}

\author{
Margaret Hodgins \\ Department of Health Promotion, National University of Ireland, Galway, Ireland \\ Sarah MacCurtain \\ Department of Work and Employment Studies, University of Limerick, \\ Limerick, Ireland, and \\ Patricia Mannix-McNamara \\ Department of Education and Professional Studies, University of Limerick, \\ Limerick, Ireland
}

\begin{abstract}
Purpose - Bullying affects at least one-third of the workers through either direct exposure or witnessing, both of which lead to compromised health, and as a result, reduced organizational effectiveness or productivity. However, there is very little evidence that organisations provide effective protection from bullying, and in fact, the converse appears to the case. The purpose of this paper to explore the role of both individual and organisational power in the creation and maintenance of the problem. Such an approach moves away from the specific practice of identifying "bullying" that typically engages targets and perpetrators in a dance that is really just around the edges (Sullivan, 2008) of a larger problem; a culture that permits the abuse of power and ill-treatment of workers, in both practices and through organisational politics.

Design/methodology/approach - This paper elucidates key problems with organisational response as identified in the literature and critically examines weak organisational response to workplace bullying using the power theory, arguing that while overt approaches to addressing bullying appear to be underpinned by a simplistic, functionalist understanding of power, practices on the ground are better explained by more sophisticated "second-dimension" theorists.

Findings - There is a need for organisations to move beyond the current individualistic understanding of bullying towards a more nuanced understanding of how anti-bullying policies and procedures are themselves an exercise in institutional power protecting and reinforcing dominant power structures.

Research limitations/implications - The literature from which this paper is drawn is limited to studies published in English.

Practical implications - The authors advocate a realistic assessment of the role of both individual and organisational power in the creation and maintenance of workplace bullying, as a way forward to plan appropriate intervention.

Social implications - Workplace bullying is problematic for organisations at several levels, and therefore for society.

Originality/value - That power is relevant to workplace bullying has been apparent since the work of Brodsky in 1976 and Einarsen's early work, this paper builds on a the more nuanced work of McKay (2014), D'Cruz and Noronha (2009), Liefooghe and MacDavey's (2010) and Hutchinson et al. (2010), exploring the organisational response to the raising of bullying issues by individual employees as an exercise of power.
\end{abstract}

Keywords Workplace bullying, Organisational response, Power theory

Paper type Conceptual paper

(C) Margaret Hodgins, Sarah MacCurtain and Patricia Mannix-McNamara. Published by Emerald Publishing Limited. This article is published under the Creative Commons Attribution (CC BY 4.0) licence. Anyone may reproduce, distribute, translate and create derivative works of this article (for both commercial and non-commercial purposes), subject to full attribution to the original publication and authors. The full terms of this licence may be seen at http://creativecommons.org/licences/by/4.0/ legalcode

Power and inaction

Received 3 October 2019 Revised 17 December 2019 28 July 2020

Accepted 28 July 2020 
IJWHM

13,3

266

\section{Introduction}

Bullying affects at least one-third of workers through direct exposure or indirect witness exposure, both of which lead to compromised health (Hockley, 2002; Nielsen and Einarsen, 2018), and by extension, absenteeism (Hauge et al., 2010; Kivimäk et al., 2000) and reduced organisational effectiveness or productivity (Giorgi et al., 2015). While one might assume that this would galvanise organisations into developing robust preventative and ameliorative practices, the converse is often the case. Organisations appear to be remarkably poor at either preventing or providing effective protection from bullying (Einarsen et al., 2011; Hoel, 2013; Hurley et al. 2016; Klein and Martin, 2011; Rayner and McIvor, 2008; Tuckey et al., 2018; Vickers, 2012). This paper critically examines weak organisational responses to workplace bullying using the power theory and argues that while overt approaches to addressing bullying appear to be underpinned by a simplistic, functionalist understanding of power, practices on the ground are better explained by the work of second-dimension theorists such as Bachrach and Baratz, Lukes and Gaventa. Specifically, a significant contributory factor to poor organisational response to bullying is the subtle and malign exercise of organisational power. There is a need for organisations to engage at a deeper level, moving beyond the current individualistic understanding of bullying towards a more nuanced understanding of how anti-bullying policies and procedures are themselves an exercise in institutional power protecting and reinforcing dominant power structures.

The paper elucidates key problems with organisational response, as identified in the literature. We then outline approaches to studying power and apply these to what we know of the experience of bullying and of organisational responses, synthesising findings from three of our studies that involved interviews across six workplaces, two public sector and one voluntary organisation and three publicly funded universities (49 interviews in total). Details of these studies have been published elsewhere (Hodgins et al., 2018; Hodgins and Mannix McNamara, 2017; Hodgins and Mannix McNamara, 2019) [1].

\section{Workplace bullying and the protection of workers}

Comparison of prevalence rates of workplace bullying across and even within countries can be difficult due to the variations in methodological design and operationalisation of the bullying construct (Bentley et al., 2012; Notelaers et al., 2006). Nielsen et al., in a meta-analysis of 86 studies, while cautioning against comparisons without due consideration of the methodological moderators of location, measurement instrument and sampling strategy, arrived at an average figure of $14.6 \%$ (Nielsen et al., 2009). Witnessing bullying is measured less frequently, but typically is reported at either similar or higher levels (Salin and Notelaers, 2017; Sprigg et al., 2010). For example, a national US study reported 19\% directly experiencing workplace bullying, with a further 19\% witnessing bullying (Namie, 2017), while a study of UK employees found a rate of $25 \%$ directly bullied in the past five years, with $46 \%$ witnessing in the same timeframe (Hoel and Cooper, 2000). There are well-established patterns across empirical studies, with workplace bullying more prevalent in large organisations (Hodgins et al., 2018; O'Connell et al., 2007; O'Moore, 2000), in public sector organisations (O'Connell et al., 2007; Task Force on the Prevention of Workplace Bullying, 2001; Zapf et al., 2011) and organisations that are male-dominated (Einarsen and Skogstad, 1996; Hayman, 2015), evidencing the importance of institutional context.

Workplace bullying is clearly a serious problem for workplaces. When targets who have direct experience of bullying and those who witness bullying are combined, a greater proportion of workers are effected compared to those who report musculoskeletal problems (22-25\%) (Schneider and Irastorza, 2010) and work-related stress (28\%) (Russell et al., 2018). The impact of bullying on the individual includes depression (Niedhammer et al., 2006), anxiety (Quine, 1999) and post-traumatic stress disorder (Balducci et al., 2011). Both associations and cause-effect relationships have been demonstrated between bullying and 
suicidal ideation, chronic pain, sleep difficulties and mental ill-health, across a number of populations and countries (Nielsen and Einarsen, 2018). Witnesses or bystanders can also be affected (Mayhew et al., 2004; Niedhammer et al., 2006; Vickers, 2012). The organisational outcomes associated with workplace bullying include higher levels of occupational stress, sick leave, absenteeism and job dissatisfaction (De Wet, 2014; Kivimäki et al., 2000; Quine, 1999).

Protecting workers from bullying through legislation has, to date, not been particularly effective. Few countries possess a robust legal framework with a high level of coordination between governments and social partners, which is considered requisite to provide the maximum protection for employees from bullying and related forms of ill-treatment (Giaccone et al., 2015). Even in countries with a strong focus on prevention, e.g. Sweden, the legal approach has limitations. In Ireland, a country with a moderate focus on prevention, the legal framework has been criticised as being highly restrictive and ineffectual, with workers having to rely on a variety of limited mechanisms, and codes of practice being unworkable and de-contextualised (Connolly and Quinlavan, 2017; Giaccone et al., 2015; Smith, 2006; Sullivan, 2008). The question of whether it is possible to legislate for issues associated with human interactions has been raised (Hoel and Einarsen, 2010). Robust context-sensitive policy at the level of the organisation might be a more useful avenue to pursue in protecting workers. Over half (55\%) of the European Union (EU) states have some legal definitions of bullying, violence or harassment, which at least facilitates the way for organisational-level policy development. However, even at the organisational level, practice is less than optimal.

While there may be isolated exceptions, generally, it appears that organisations fail to either prevent or manage workplace bullying to minimise harm to workers (Catley et al., 2016a; Kahn and Kahn, 2012; Keashly et al., 2008; Rayner and McIvor, 2008; Salin, 2009). Evidence from studies of target or witness accounts (Hodgins and Mannix McNamara, 2017; Hodgins et al., 2018; Hurley et al., 2016; Jenkins, 2011; Klein and Martin, 2011; Mannix McNamara et al., 2017; O'Donnell and MacIntosh, 2016; Rayner and McIvor, 2008; Thirlwall, 2015), human resource managers (HRMs) (Catley et al., 2016; Cicerali and Cicerali, 2015; Cowan, 2011; Harrington et al., 2015) and consultants (Jenkins, 2011; Olsen, 2018) are confluent in reporting that organisations either fail to respond at all to bullied workers, fail to implement policy or thwart targets' attempts at redress, which serves to add further to the distress of workers.

The association between experience of bullying and turnover intention is well established (Coetzee and vanDyk, 2018; McCormack et al., 2009; Razzaghian and Ghani, 2014; Shellie, 2008). The results of studies that ask what actions are taken by bullied staff are not easily comparable, given the variation in methods of measuring bullying, the variation in response options [2] and the possibility of overlap (targets may contact HR, after contacting the trade union, and a supervisor, etc.), although despite this, offer some evidence of poor organisational response. In a US national poll study, $29 \%$ of the workers who are bullied do nothing (Namie, 2017), as is the case for $14.5 \%$ of UNISON workers (Hoel and Cooper, 2000). Descriptive studies can provide additional information on those that follow through on intention; over half of the targets report an intention to quit (57\%), while $15.4 \%$ actually do so (O'Connell et al., 2007). Other "actual" quit rates reported include 28 (Namie, 2012a, b), 27 (Rayner, 1997), 22 (Silvia et al., 2010) and 11\% (Task Force on the Prevention of Workplace Bullying, 2001).

An anti-bullying policy is the most common organisational intervention to address workplace bullying (Hoel, 2013; Richards and Daley, 2003; Salin, 2003). Anti-bullying policies present important visible standards for interpersonal behaviour, signalling recognition that bullying is unethical and highlighting employees' rights not to be exposed to it. Yet, there are very few attempts to evaluate their effectiveness. It has been demonstrated that the presence of a policy is a significant predictor of lower rates of workplace bullying (O'Connell $\mathrm{et}$ al., 2007), and employers with a robust policy in place are less likely to lose a case against them on
Power and inaction 
IJWHM

13,3

ground of bullying or harassment(Rockett et al., 2017); yet, qualitative studies have found negative experiences even in organisations with an anti-bullying policy (Hodgins and Mannix McNamara, 2019; Hodgins et al., 2018; Vickers, 2012), indicating that it is not a straightforward relationship. Policy may be better, broadly speaking, than no policy, but how it (or if) is implemented depends on a range of factors. A cynical view is that policy may reduce litigation against the organisation, which in fact protects the organisation rather than the employee. However, it may be unfair to impute such negative motivations on all senior managers, and it is fair to say that anti-bullying policies are complex interventions (Cambell et al., 2000) in complex settings, i.e. there are many contextual and implementation factors at play. For example, awareness of policy is a pre-requisite for use, yet organisations do not always inform staff of the availability of a policy. Only $67 \%$ of the Finnish municipalities gave information on their policy to staff, and only $27 \%$ provided training for managers (Salin, 2009). In a study of two Irish public sector organisations, one-quarter did not know or had incorrect information about their organisation's policy (Hodgins, 2004). More importantly, employers may well be remiss in following their own policies (Ferris, 2004; Hoel, 2013; Namie, 2012a, b; O'Higgins and Kiernan, 2015). While 38\% of the targets in a US study reported the presence of an anti-bullying policy, for $35 \%$ of these, it was applied unevenly or was considered too weak (Namie, 2012a, b). In a UK study, only 30\% of the respondents felt their organisational policies were effective for addressing bullying, while $27 \%$ felt procedures were not effective (Evesson and Oxenbridge, 2015). To the extent that formal action can be taken as an indicator of confidence in the organisational system (Shallcross et al., 2013), it is worth noting that very few employees who believe they are bullied take formal action. Where a specific grievance procedure is mentioned, those who take this route are few: 20 (O'Connell et al., 2007), 9 (Task Force on the Prevention of Workplace Bullying, 2001) and 8 (Hoel and Cooper, 2000). Low confidence may be well placed; a study of public service personnel in Australia found that of 155 complaints received between 2010 and 2016, 72\% were unsubstantiated (Crimp, 2017).

The contextual factors, we argue here, are related to the disconnect between the devising of policy, which is based on a one-dimensional approach to power, and the implementation of policy, which is better explained by second-dimension theories, i.e. the second face of power (Bacharach and Baratz, 1962).

\section{Theories of power}

Power is studied in the social, political, management and physical sciences. In the physical sciences, power has quite a specific meaning; it is defined as a measure of the rate at which work is done or which energy is transferred. While the notion of "force" carries over from physics, in that we often understand power in a social context to be about one person forcing their will on another; power in organisations is infinitely more complex. It can be seized, resisted, eroded, can ebb and flow; can be used both benignly and malevolently; and can be wielded by a person or group, with or without them being present. It is described as a highly contested concept with multiple meanings, including being visible, hidden and invisible (Gaventa, 1980), or as acknowledged by Clegg et al., it works best when seen least. Mintzberg describes it as a "sly and elusive phenomenon" (Mintzberg, 1983) (p. xiv) and maintains it is experts who agonise as to what constitutes power, while ordinary people have no trouble with the concept; "they know what it means to have power and they can sense who has it" (p. 1). The findings from qualitative studies of workplace bullying would strongly support this contention.

In 1959, French and Raven identified five sources or forms of power that operate in organisations; power based on position (legitimate), on personal skills and charisma (referent), on specialised knowledge (expert), on the ability to reward those who follow (reward) or based willingness to use negative influence (coercive). While this analysis and 
articulation of forms of power is as valid today as when first articulated, the power theory has evolved considerably since and has concerned itself not just with the overt exercise of power, but the need to consider concealed forms of power and the nature of both resistance and quiescence.

In the same way that power theorists such as Bachrach, Baratz, Gaventa and Lukes did not confine themselves to asking "how is power exercised", but asked why do the powerless remain oppressed, we move from asking "why do organisations fail to respond appropriately to workplace bullying", to ask "why are the bullied so disempowered, so ill-served by their own organizations"? Much of the analysis and commentary on bullying in workplaces presents it as a conflict between the target, an individual and the perpetrator, also an individual. It is argued here that power is exercised in the organisation in a more covert manner, to protect the organisation, rather than the target, and as such, it is necessary to consider a critical analysis of power relations in organisations. Specifically, organisations stand to gain more from poor response to bullying; so while overtly proclaiming to censure or even outlaw bullying to protect workers, drawing on policies that reflect and protect dominant power structures, the implementation of these policies is an exercise in the use of covert power to protect the organisation rather than solve the problem. In essence, the policies and procedures are themselves a managerial tool to control employees.

Early approaches to power are the functionalist/behaviourist approaches, described as primitive discourses of power (Kearins, 1996) [3]. Such approaches view power as a phenomenon that is possessed by individuals or groups, exercised in the enactment of behaviours, visible and subject to challenge in an open system. Power in an organisation is understood as the capacity to influence others, exercised to ensure compliance with organisational goals. In this rational view, power relations in organisations are reduced to "superiors rightfully exercising power over subordinates in order that the supposedly more noble ends of the former are served" (Kearins, 1996) (p. 5). More insidious forms of power are not considered. This approach is sometimes called the one-dimensional approach, or the first face of power. An example is found in the work of Robert Dahl who defined power as A having power over B to the extent that he/he (sic) can get B to do something that B would not otherwise do (Sadan, 2004). Not only can it be possessed and seen, but this view of power assumes people who wish to challenge power raise their grievances and "political issues", in overt fora and decision-making arenas. Dahl assumed that such fora are open to everyone who wishes to use them (Dykema, 1985). Therefore, by extension, not raising grievances or issues is due to the acceptance of the agenda and decisions of the powerful, or to inertia, or indifference. It can, therefore, be cast as their own fault, i.e. victim-blaming. In the view of the functionalist/behaviourists, it is non-political, i.e. B's failure to challenge or rebel against A is not seen to be a function of B's powerlessness (Gaventa, 1980) (p. 8). We now explore antibullying policies through the lens of the functionalist/behavioural theory.

\section{The overt position of the organisation}

Anti-bullying policies typically contain a declaration of commitment to the protection of employees from harm due to bullying, offer a definition of bullying, give examples of behaviours that constitute bullying and outline the steps that will be taken when a complaint of bullying is received. This usually includes an informal approach, which allows a designated person address the matter with the alleged perpetrator to ascertain whether the matter can be de-escalated with increased awareness of how their behaviour has affected another staff member, and if this fails, a how formal grievance procedures can be invoked. The behaviours listed in anti-bullying policies are usually overt, noticeable and measurable (Box 1).

These are consistent with the understanding of power that underpins the first face of power; power is exercised overtly and visibly in order that "A", an individual, subjugates "B", 
IJWHM 13,3

\section{0}

\section{Box 1. Sample of behaviours listed in anti-bullying policies [4]}

Belittling or criticising others in front of peers/other staff

Verbal abuse

Slandering a staff member or manipulation of their reputation by gossip and ridicule

Use of aggressive or obscene language

Unwanted physical contact

Displaying hostile or aggressive behaviour

Overruling someone's authority

Giving impossible deadlines

Excessive monitoring of work

Reducing work tasks to below a person's capability and qualification without prior discussion or explanation

Persistent fault finding

an individual. It is evident in many accounts of bullying, where perpetrators shout, publicly ridicule, undermine and physically threaten workers. It is an accurate depiction of how some bullying is enacted and experienced, and there are myriad examples in qualitative studies of these behaviours. From our studies, one such experience illustrates:

He came in and saw that I'd moved those and(. . .) he saw red, and laid into me for touching his stuff without asking him. And then threatened to throw me and my stuff out the window. Raised his hand to me (Pamela, E) [5]

These types of behaviours are experienced by many targets, but even allowing those policies often include the caveat that the examples are illustrative but not exhaustive; it is also the case that there are many other ways in which bullying is experienced that are not captured by the first face of power. Although bullying is often understood as or perceived to manifest as explicit aggressive behaviour, it usually will take more subtle forms. Much bullying as experienced is understated and insidious. Bullying behaviours can be conducted in secret (Caponecchia and Wyatt, 2011) and can include passive actions, such as excluding from meetings, networks, denial of training opportunities (Rayner and McIvor, 2008) or "the silent treatment" (Keashly and Jagatic, 2011, p. 13). The subtlety of bullying can lead targets to question themselves and to be too embarrassed to bring their concerns to HR, as one target in our studies articulated:

And it was very, very, subtle, so, there was no way you could bring a case, because, it was that subtle, you know (...) It's all the things, the soft bullying. You know, excluding you from meetings, then therefore you couldn't really do your work properly. . .holding back information, you know, things like that, very, very, subtle. (...) You nearly doubt yourself, because it's very hard to explain it, because sometimes you sound like you are just being petty, but when you actually experience it and when it's a long period of time... (Mary, A).

Power can be used for personal gain and ambition, to minimise worker resistance and to ensure compliance with dominant ideologies (Kearins, 1996). The micropolitics of organisational life include these subtle uses and abuses of power (Vredenburgh and Brender, 1998), some of which are either independent of or even antagonistic to organisational goals and are not captured by the view espoused by the functionalist/behaviourist (Kearins, 1996) discourses of power.

The functionalist/behaviourist approach to power has been criticised for its static or rational conception of organisational life, deriving as it does from mechanistic views of the organisation. The language in the Irish Code of Practice, for example, refers to the actions to be taken in the event of a complaint being upheld, to eliminate "the hazardous behaviour" (Health and Safety Authority, 2007) (p. 18). Not only does this imply that behaviours are in some way separate to the people who enact them, it is remarkable in its ignorance of the 
sensitivity needed to handle difficult bullying situations (Sullivan, 2010). Policies usually infer that once an alleged perpetrator is informed of their negative behaviour and the damage it is causing, they will agree to undertake some behavioural change. There is an assumption that bullying is "behaving badly", but that this bad behaviour is an exception, and that it will be curbed by admonishing perpetrators. Further, it presents bullying as a dyadic problem rather than an organisational one. This fails to acknowledge that the workplace is a complex political system. Politics are a normal, if unpalatable aspect of organisational life (Clegg et al., 2005). Power is exercised, obeyed, resisted and subverted on a daily basis in workplaces. Everyone participates, although in varying degrees, usually without much collateral damage. It is only when the normal power plays segue into a toxic relationship that the target will consider that they are being bullied. The bullying experience cannot be surgically excised and isolated from everyday relations. Despite the fact that most descriptions of workplace bullying in the literature list "power imbalance" as an element, policies typically do not refer to this or recognise this in the implementation of procedures. An analysis of 15 anti-bullying policies found none emphasised the power imbalance aspect of bullying, only one organisation explicitly included it in their definition and only one other mentioned perpetrator intent. In this sense, policy is, or is almost, deliberately power-blind.

A striking example of power-blindness can be found in the informal process typically outlined in policy. This involves designated contact persons who are given authority by the employer to act as initial facilitators where bullying is alleged (Health and Safety Authority, 2007). The contact person might address the matter with the alleged perpetrator to ascertain whether the matter can be de-escalated or how a formal grievance procedures can be invoked (Box 2).

It is naïve to assume that the contact person (a member of staff) can realistically be independent and not involved in any other way. Studies reveal that targets recount listed or named contact persons who are friends of the perpetrator, or even those who are perceived to be the perpetrator, or to whom disclosure would increase their own vulnerability. One participant from Organisation C felt completely compromised in this regard:

Our bullying and harassment person was another team leader who was a friend of this particular guy. . It complicated it hugely... Well I just felt he would not be, he would not be on my side, that he might say-oh well, you know him, he's just gruff, that's the way he is. He was a gruff person, lots of people are, that's fine. . . but I just felt, no, I cannot, I cannot go to him about this, because I'm just going to be seen as 'the woman'-you know, cannot deal with this gruff guy (Nuala, C).

Ultimately, the employer is the final adjudicator in an investigation of a bullying complaint. Even where an external consultant has been appointed, their recommendations are not usually enforceable, but are "at the pleasure" of the organisation. Significant power remains with the employer with no acknowledgement that this process cannot but disempower targets (Sullivan, 2010).

\section{Box 2. Excerpt from the Irish Code of Practice on the prevention and resolution of bullying at work}

As part of the Bullying Prevention Policy employers should name a "contact person" who can listen and advise about complaints of bullying at work and explain the procedures in place to resolve it. These individuals should receive appropriate training. The Contact Person role is a voluntary role of facilitation to act as the first point of contact for someone who believes that he or she is being treated in a bullying manner. The Contact Person is nominated, through agreement with the employer. He/she has a listening brief and is a reference point for the complainant, and he/she could, for instance, provide the complainant with a copy of the policy, outline the routes available and explain the roles of personnel involved. The Contact Person does not get involved in any other way in the complaints procedure and is not an advocate for either party. 
IJWHM 13,3

A more complex exercise of power is evident both in the enactment of bullying and in the response to it, and it is to this we now turn.

\section{The covert position of the organisation}

Advances on functionalist/behaviourist conceptions can be found in the work of Bachrach and Baratz, and latterly, Lukes and Gaventa (Gaventa, 1980). Where Dahl's view is taken to describe one face of power, Bachrach and Baratz's work is an implicit critique of this view, positing the existence of a second, more sinister face of power.

Bachrach and Baratz's position is that the powerful not only exercise power in the making of decisions in a visible or overt democratic process, but that a second, covert, dimension also exists; power is exercised to limit what decision-making takes place, and therefore to prevent certain conflicts or problems being even vocalised or exposed. This is described as hidden power, as it is visible only to a small group of those in power, the decision makers (Gaventa, 1980). This exercise of power can operate through simply having the reputation of power. In having such a reputation, a powerful actor can prevent political action without taking action itself. In this articulation of power, the powerful actors predetermine the agenda. This has the effect of protecting and reinforcing their powerful position. In organisations, according to the two-dimensional theory, powerful actors can categorise certain issues as non-issues by subtle means such as insisting on very limited parameters regarding the causes of and/or solutions to certain problems (Sadan, 2004). The exercise of power in the two-dimensional theory is, therefore, more sinister.

As applied to organisations, second-face power theorists argue that not only does A (usually the employer) have power over B (usually the employee) to the extent that he/she can get $\mathrm{B}$ to do something that $\mathrm{B}$ would not otherwise do, but A creates institutional practices or conditions that protect A's interests, and B is prevented from doing anything that might be detrimental to A's interests.

In this context, workplace bullying can be seen to be detrimental to $\mathrm{A}$, insofar as the employer is seen to have allowed bullying to take place and has therefore been negligent in allowing it to occur (Sullivan, 2008), and in certain jurisdictions, this makes them vulnerable to redress claims. Management have a vested interest in not allowing bullying matters to surface either within the organisation generally or in a wider context (e.g. with the public, with competitors etc.). Organisations are not generally disposed to secure the well-being of the staff, at least over the goal of averting productivity loss (Klein and Martin, 2011). Managers fear litigation even though actual compensation costs may be low. Relatively speaking, losing face in cases related to harassment of protected classes is particularly threatening to employers (Beale and Hoel, 2011). Of course, the easiest way to prevent bullying cases being taken and publicised is to ensure bullying does not take place in the first place. However, employers also stand to gain from bullying (Beale and Hoel, 2011) a perspective not frequently explored in the workplace bullying literature, with the notable exceptions of Liefooghe and MacDavey (2010) and D'Cruz and Norohona (2009), who consider the extent to which the organisation is a perpetrator of bullying. As part of the labour process, managers can and will use various means to maximise production and maintain control, and this can and does include bullying tactics, as the boundaries between unacceptable behaviour and legitimate management practice can be either inadvertently or deliberately blurred. The hierarchical structures and the political nature of organisations mean that junior managers stand to benefit in terms of their own personal career agenda in the controlling of ordinary workers and senior managers also have "much to gain either by directly lending their support and loyalty to junior managers who bully workers, or at least by doing so indirectly by condoning or ignoring such bullying behaviour" (Beale and Hoel, 2011) (p. 10). There is a potential conflict of interest in the employment relationship, providing an important 
backdrop for exploring how the second face of face underpins the way in which organisations respond or fail to respond to workplace bullying (Beale and Hoel, 2011; MacMahon et al., 2018).

The second face of power is restrictive. It is exercised in such a way as to load the dice in favour of the organisation. It is hidden, not always evident in its exercise, and is subtle, implicitly shaping of the conditions that effect how issues, such as workplace bullying, are dealt with. It is achieved through a number of practices, which together are termed "the mobilisation of bias" (Bacharach and Baratz, 1962) and which are abundantly evident in the accounts of both HRMs and consultants/practitioners and of targets.

A number of these have been identified (e.g. Bacharach and Baratz, 1962; McCalla-Chen, 2000; Sadan, 2004) and are summarised in Figure 1. We discuss these in detail below. These practices are not mutually exclusive. It is feasible that in any one organisation or situation, they could overlap or interlock.

The second face of power also finds expression in the concept of organisational outflanking, introduced by Mann (Sadan, 2004). Sadan describes this as those who are advantaged in organisations through the possession of resources, also having the advantage in power relations, and using this to "outflank" others. Outflanking includes tactics such as ignorance and isolation; if people are presented with "rules of the game" that they were hitherto unaware of, they are outflanked. If they are prevented from finding out about others who share the same fate, they are outflanked (Sadan, 2004). The experiences of targets evidence these situations, and we include these in our discussion.

\section{Mobilisation of bias \\ Institutional inaction}

If an organisation does not have an anti-bullying policy, no investigation or remediation can take place. This is clearly an example of institutional inaction. Although there has been an increase in policy coverage in the UK (Hoel, 2013), it is still the case that many organisations have no policy. Across the EU27, only $30 \%$ of the workplaces have procedures at the
Power and inaction

273

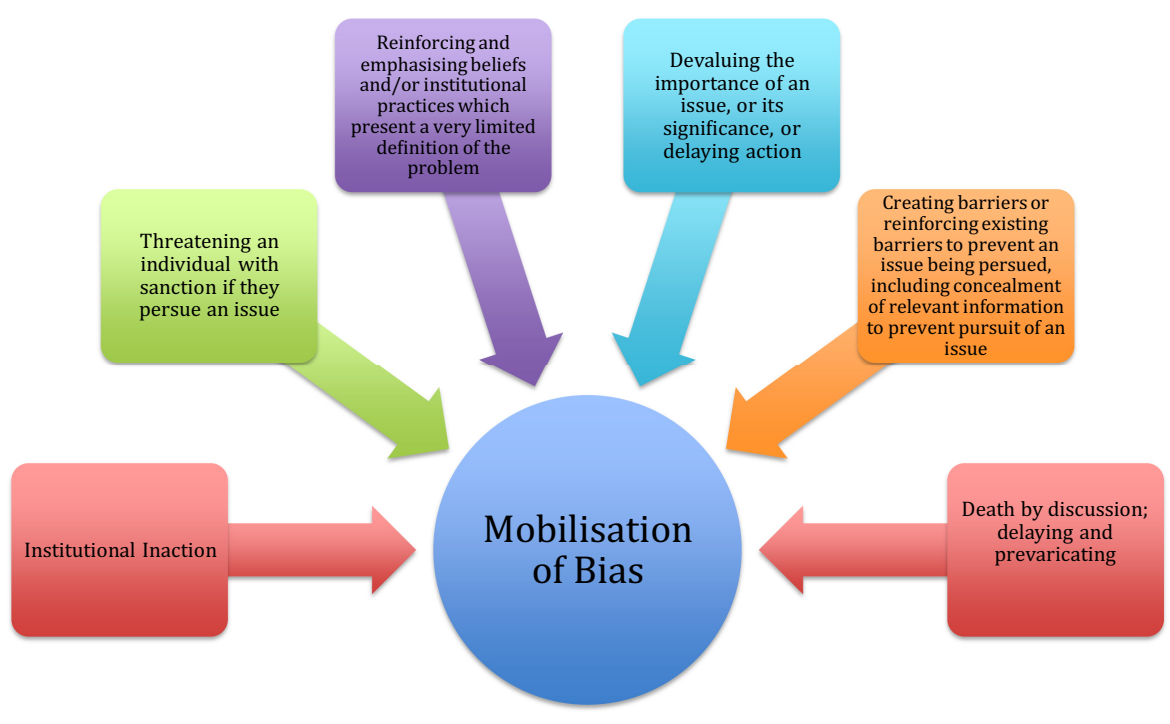

Figure 1 . Mobilisation of bias 
IJWHM 13,3

\section{4}

company level to address bullying and harassment, although there is considerable variation from state to state. In Ireland and the UK, $80 \%-90 \%$ have put procedures in place. Coverage is moderate (around 50-60\%) in the Scandinavian countries, Belgium and The Netherlands, although only $20 \%$ of French and $5 \%$ of Greek organisations have policies (Giaccone et al., 2015). Just over half of the organisations in New Zealand (Catley et al., 2013) and just under half US workplaces have policies (Namie, 2012a, b).

These studies show it is likely that many workers have no recourse to a policy and therefore no protection. This may not be a simple oversight; for some employers, it can be a deliberate strategy; e.g. based on the belief that having a policy could lead to false allegations (Jenkins, 2011; O'Connell et al., 2007). A study of HRMs in the hospitality sector found nonintervention was defended on the basis that informal approaches obviated the need for paperwork, and that chefs (usually the perpetrators) were hard to replace (Bloisi and Hoel, 2010). Having policies that only cover matters protected in legislation (e.g. harassment based on race, gender) can be used to exclude bullying behaviour that does not meet a legal definition and therefore fail to protect from many other types of bullying (Cowan, 2011). Organisations that do not have anti-bullying policies are effectively controlling the agenda to deny the concept of bullying altogether. It is critical that policies state explicitly and unambiguously that bullying will not be tolerated (Vega and Comer, 2005). Codes of conduct simply tell workers to behave nicely (Tuckey et al., 2018) and may not contain specific contact points or guidance for action where there are breaches of the good behaviour that such codes promote.

Even where policies are in place, they may be openly ignored (Hurley et al., 2016; Klein and Martin, 2011; O'Donnell and MacIntosh, 2016), and as discussed by Vickers, may be little more than "an empty shell" (Vickers, 2012) (p. 546). More often, however, some form of action is considered or is taken, but rarely leading to any vindication or satisfaction for the target. In fact, targets often feel further victimised and intimidated (Hutchinson and Hurley, 2012), and in this way, management responses to the use of bullying procedures can construct employee silence (MacMahon et al., 2018).

\section{Threat of sanction}

There are numerous references in targets' accounts of threats if they pursue a bullying issue, especially through the formal route. While some targets have experience of threats articulated, for many, the threat simply operates through the organisation's reputation for power, a clear example of the exercise of second face power (Gaventa, 1980). Either way, evidence from targets' accounts plainly indicate that doing nothing is not, as the functionalist/behaviourist approach would argue, apolitical.

Targets who "do nothing" are making this choice, not in an apolitical way, but precisely the opposite, because the power of the perpetrator or the organisation or both is perceived to be too great. Many target accounts reveal fears of repercussion, reprisals, fears of being labelled as a nuisance or a snitch, fear of looking foolish or fear of being let go (Caponecchia and Wyatt, 2011; Ferris, 2004; Hodgins et al., 2018; Lewis, 2004; Mannix McNamara et al., 2017; Rayner and McIvor, 2008). It is certainly not apathy that explains non-response - more often than not it is fear and/or futility. Two examples from our work illustrate:

If you complain about a senior, they might rattle your wagon at a senior level and you'd be, it is not worth your while! ... you'd find that staff would never report it again because, look, it would nearly turn full circle on them... (Victor, D).

Yeah and if it was to be on their record or if it was to be in a reference afterwards I think people would be concerned about that and then maybe being labelled as a troublemaker or somebody who is ...... well you do not want her in your department. ..... (Helen, F). 
Indeed, targets frequently make a very clear decision not to invoke the anti-bullying policy, based on their perception of the greater power of both the bully and the organisation:

Iknew there was a bullying and harassment policy. It was obvious to me that this was targeted at me. That he was bullying me. He was targeting me. There was no doubt about it. Ihad lots of emails from him, in writing. I could easily have, you know, walked up to HR. Or, I could have gone to our person I did not, why did not I? - Because I was just in the door. Because I wasn't a permanent member of staff (...) I guess I thought that there was an expectation that I was a team leader, and you know, you've been given this position of responsibility, and you know what - you should be able to deal with this. You should be big enough to deal with this problem. Yeah - and I kind of felt, if I cry, if I go crying to somebody over this, then will they say when a future opportunity comes up in management, will they say do you remember her-remember the crying, remember the tears over yer man? What if? - there's a few difficult people down there-she will not be able to cope, so I thought, no I cannot, I do not want that on my record-I do not want managers remembering that (Nuala, A).

\section{Reinforcing beliefs and/or institutional practices that present a very limited definition of the problem}

Much of the literature on workplace bullying is dominated by psychological perspectives, with a focus on interpersonal behaviours and dyadic conflicts (D'Cruz and Norohona, 2009; Hutchinson et al, 2010; Liefooghe and MacDavey, 2010; Tuckey et al.,2018). This emphasis on particularized "aberrant" behaviour facilitates a focus on individual psychological conditions or illnesses that result from exposure to it, and accordingly, individually focused solutions. A systematic review of interventions reported a strong attachment to the notion that workplace bullying and incivility are problems of interpersonal behaviour, with many of the interventions identified addressing individual behaviour change only, aiming to reduce bullying or incivility through educational programmes, increasing awareness of and recognition of negative behaviours or coaching "better" responses to negative behaviours (Hodgins et al., 2014). This singular, agency-based perspective (Hutchinson et al., 2006) is reflected in popular and media accounts of workplace bullying (De Conto-Garbin and Fischer, 2012). Bullying is individualised, with perpetrators cast as the villains of the piece and targets as vulnerable or unwitting unfortunates. Even in film media, workplace bullying is predominantly portrayed as abusive tyrannical bullies intimidating younger or more junior targets, where the target rarely triumphs (Georgo, 2017). This individualised perspective is also a strong theme in HRMs accounts of experiencing or addressing bullying.

The main reason that bullies remain powerful is that they manage to impose their definition of the situation on the target, either directly or to HR (Lewis, 2006a, b). Either way, there is evidence HRMs or managers "frame" the situations or difficulties presented to them by targets as "just" interpersonal conflict (Jenkins, 2011; Klein and Martin, 2011), as personality difficulties (Ferris, 2004; Hutchinson et al., 2010; Vickers, 2012) or as targets' defensive reactions to managers questioning their performance (Crimp, 2017; Harrington et al., 2015), but not as bullying. From the employer's perspective, what is being named as bullying may just be the job of management, and the "target" is simply resisting being managed. In one of the few studies that explore the perspectives of accused bullies, they did not see their behaviour as bullying, but as part of their job as a manager (Jenkins, 2011). This, then, can be seen to be both reinforcing popular belief and as presenting a limited definition of the problem. Targets report bullying being represented to them as a communication problem (Hodgins and Mannix McNamara, 2017) or as personal weaknesses (Thirlwall, 2015; Vickers, 2012). The very act of re-interpreting targets claims is evidence in itself of an exercise of power, where the institution re-frames the problem to one which it can bury, dismiss or blame on the target's vulnerabilities or ignorance:

...they kept on using the word, 'personality clash' and it wasn't a personality clash, there's nothing worse than not being feckin' listened to... (Dana, C).

Power and inaction 
IJWHM 13,3

That really, you're just overreacting and, you know, your view of it is wrong, it's ..... you're making it into a bigger deal than it is (Pamela, E).

As long as bullying is seen to be a function of the individual's nature or personal vulnerabilities, the organisation can absolve itself from taking action. This can apply to the behaviour of either the target or the perpetrator. In Fiona's experience, the perpetrator was protected, being senior, and his bullying behaviour cast as a personality quirk:

But what disappointed me more than what happened was the lack of any action taken at all. All I wanted from the Head was not to have to deal with this individual (. . .) and he sat and said 'you know he IS a particular character' and that we all have different cultures of doing things and I'm sure you appreciate that (name of perpetrator) is a big asset to this department'.

In one the first studies of workplace bullying, Leyman observed the tendency to demonise targets and how this had the effect of rendering them unworthy of the right to be protected (Leymann, 1996). Blaming the target remains a frequent theme in many qualitative studies, as Peggy's opinion here illustrates; "So they will just ... they will basically make the employee feel that they are at fault rather than the actual person who really is at fault". A similar manifestation of individualisation of the problem is the expectation that targets "take ownership" of the problem, effectively bouncing it back to the target, under the guise of HR advice:

I'd be saying 'But what do you want? And if you want this to stop you have to take ownership of it' and I think that can be the big ... that's one of the biggest challenges because people come to HR and they'd say 'I'm being bullied by my line manager, I want it to stop and I want you to do something about it' and there can be a misunderstanding there of what our role is and what their responsibility is (Patsy, E).

\section{Creating or reinforcing barriers and/or concealment of information}

More generally targets find that when they raise issues with the HR, obstacles are placed in their way; fine print in policy or "rules" that they were not aware of, e.g. having to "classify" the problem (as bullying or harassment) before HR will deal with it, having to document times and dates of interaction or targets having to undergo an occupational health and safety (OHS) assessment. These are often normal, even good practice in HR terms, there is usually nothing sinister about the practice. It is the unfolding process and the casual drawing out of cards in the game that disempowers targets. Many targets may be asked to produce a requirement they were hitherto unaware of or is very difficult to find, at a time when they are struggling with stress or compromised health, and in a way that reinforces the power of the organisation over them. In this way, these tactics are clear examples of organisational outflanking (Sadan, 2004) and of the organisation having control over the "rules of game", obscuring rules to control the agenda, the agenda being to either prevent a complaint going forward or to thwart a target as they make a complaint. The invoking of the principle of natural justice is a particular example.

The principle of natural justice refers to the right of an alleged perpetrator to know what they are being accused of and the right to reply. Although one might expect that this principle is implicit in any organisational process, and therefore should not come as a surprise to workers, many targets are surprised when it is applied (Hodgins and Mannix McNamara, 2017; Hodgins et al., 2018) and can feel that its application is anything but fair. In some organisation, the guidelines for natural justice are contained in a separate document to the anti-bullying policy. In the following example, Paddy (organisation E) describes the difficulties in relation to balance and equity as a way of adding insult to injury, and as a deterrent to using the procedures, as staff already feel wronged or ill-treated. For some, there is nothing natural or just about this: 
They have the whole document on bullying in the workplace and everything is said and everything there and they have the document but low and behold, that document could be used to hit you over the head if you're a victim because if you're saying ... suddenly it becomes 'everybody's equal here, they have as much right', the bully or the guy that does the bullying has as much right as you, so you if you, if somebody takes a bullying claim, you are in as much trouble as the person doing the bullying in your opinion. So you do not even go near it because it can be used against you (Paddy, E).

HR or senior managers outflank targets with their superior knowledge of organisational processes and restrictions and limitations to their application (Sadan, 2004). There are numerous examples of organisational outflanking in targets' accounts in our studies, and those of others, with Thirwall's examples of organisational re-jigging and re-buffing most clearly illustrating this process (Thirlwall, 2015). Further examples emerged in our work, as outlined below.

One target experienced a very negative encounter in a specific incident where she was shouted at and threatened over the altering of a teaching space for a new post-holder without consultation. When she sought help, she describes being told "oh this is really serious we have to investigate it but actually it's not bullying. . . and actually the union said afterwards. . no you cannot use that word" (Oona, B). The explanation of why the issue did not constitute bullying and as such was not catered for in the organisation's policy was because the behaviours she experienced were part of legitimate recommissioning of facilities.

The requirement to present documented evidence clearly acts as a barriers to workers who wish to make a complaint about bullying. Targets of workplace bullying are often slow to identify or admit that they are being bullied (Hodgins, 2004; Lewis, 2004, 2006a, b), because they feel shame or embarrassment (Caponecchia and Wyatt, 2011; Lewis, 2004). Denotative hesitancy (Thirlwall, 2015) feeds into this type of bias mobilisation. Given the fact that bullying evolves over time and is a process (Lewis, 2006a, b), few think of recording early instances of uncomfortable incidents and unpleasantness, as they may not (yet) be typical and may indeed be isolated events. By the time a pattern has emerged, much of the early situations will have gone un-recorded (Jenkins, 2011). A target voiced this concern also when was told by management she should have documented her encounters with the alleged perpetrator, although this, in her opinion, would have been counterproductive:

I cannot go through my working day writing down every little encounter, because that's just going to fill me full of rage and anxiety anyway, because I'm picking up stuff that is not there either, I think you get nearly hyper-sensitive! [...] You'll always have encounters with people that do not necessarily go well, and that's fine, but if you write every single one of them down, you'll just build them out of all proportion. So, there's a really, really fine balance between documentation, and building something that is not there (Anna, A).

Rules about timing or patterning can also create barriers for targets raising issues. Antibullying policies usually contain a definition bullying, and a specific timeframe or frequency criterion, e.g. the caveat that isolated or once-off incidents are not considered bullying. These specifications can be problematic for a number of reasons, as observed by Keashley. They must be considered in "terms of the overall frequency of contacts, for example, "perhaps the boss only yells at an employee once a month but if the employee only sees him/her once a month that is $100 \%$ of the time (...) Further, the frequency of exposure can be created (or enhanced) by the target reliving the experience, i.e. rumination”" (Keashly, 2010, p. 13).

This presented a problem for Pamela in organisation E, where the term "sustained pattern" was introduced in a way that disempowered her and could be construed as playing the rules against the target:

But it has to be a sustained pattern. And they said there were two incidences 18 months apart, not categorising any of the small incidents (. . . I I had to very ... straight away, with the formal process

Power and inaction 
IJWHM 13,3

identify as to what category it fell into, and it was like, I do not know. I'm just making a complaint on the two ... I just want to tell you what happened. Let you decide. That was the very first question, that was the very first thing I had to ... and I think that watered it down because they were saying, well, bullying is sustained a pattern over a prolonged period, whereas these two incidents were 18 months apart. And I was like, oh.

Fiona (organisation A) also had difficulty with this rule. In her situation, her line manger had an extremely aggressive outburst, which upset her greatly. However, on consulting the policy, she found that it was not repeated, even though there had been what she described as underlying tensions previously and also because he became aware that she was prepared to take notes after any further encounters. "It wasn't that there was a big run in before that but there was an underlying sort of tension and then it absolutely erupted.....I sent back that e-mail and as soon as I had sent it I could hear his door slam down the corridor and I have never been talked to like I was talked to in my office that day. . ... . .He came in. . ..he stood over me. . ... literally his arms out over me threateningly..... . how dare I. ....and how dare I talk to him like that. ....how dare I. ..”. She later discovered that other staff had had difficulties with the perpetrator, but had left the organisation. This constituted a repeated pattern, but could not be applied because they had not taken a grievance: "And you know obviously the information is there and I did find it quite strange and I do understand as well that you cannot have people kind of willy-nilly accusing people of activities and at the same time I just really felt that the burden was on the person to then kind of gather up all their evidence. . .but it is not that simple. In my situation there were clear witnesses to a particular incident (. . .) and I kind of just feel that my hands are tied because I officially did not make any complaint and I do not know I do not even know. ....I know I do not have grounds to. . ..on the current criteria policy...”.

This can also be seen to be an example of organisational outflanking by means of isolation. The very practices that on the face of it "protect" targets in terms of confidentiality clauses also serve to isolate, which in turn can facilitate depression. Targets often feel isolated in the face of bullying, as Mary from organisation A points out:

I got, I got ... down, and my self-confidence really was very low. I used to feel a bit weepy when I'd go home(. . .) I kind of stopped going in then, talking to the girl I would have worked with, because, I just felt there was no point, you know, it was kind of-I really isolated myself then after that because I just did not want to get involved with anyone.

With regard to playing the rules against the target, Anna (organisation A) felt very cheated by her organisation when she found having to take sick leave because of bullying ultimately backfired on her well-being and her intention to try to avoid confrontation and cope with the situation herself. When she went out sick, and allowed her doctor to note work-related stress on her sick leave certificate, this "automatically" triggered an OHS assessment in her workplace, which in turn led to HR requesting a meeting between her and the person whom she felt was bullying her. She was unaware this would happen and was clearly disempowered by the process:

(I) went to see my GP, and he started talking to me and I just literally collapsed in his office, and he was like, well, you cannot go back there, you know, you certainly cannot go back right now. So, without being actually aware of the knock-on consequences of what he was about to write on my medical certificate, he said, "I'm just going to put down work-related stress" so of course me kind of not thinking I said well you know fair enough (. . . ) and all of a sudden I have a letter from HR, which rocked me. . .I'll tell you our HR office have a long way to go learn how to write letters to people on the edge (...) you know, I had never actually made an allegation, but he contacted the manager, and he said you know she has to be given an opportunity to refute this, or whatever. . I I said I have not made any allegations, it's just work-related you know, but of course I had gone to the occupational health physician who. . . that was what happened. 
Devaluing the importance of an issue

Bullying can be trivialised, as evidenced by targets in Thirlwall's study (Thirlwall, 2015), for example suggesting targets can "sort things out themselves" over a cup of coffee. A common theme in many targets' accounts is that bullying is just not taken seriously (Bryant et al., 2009; Hodgins and Mannix McNamara, 2017; Hodgins et al., 2018; O'Donnell and MacIntosh, 2016). One participant in organization $\mathrm{E}$ had an altercation with her line manager, which she says lasted $40 \mathrm{~min}$ and which ended with her in tears. The altercation was witnessed by several others. She reported the incident to senior management. She was told it had been dealt with, but later became aware that "in their conversations they actually laughed about it".

Accounts from HRMs also indicate that they consider targets' complaints' to be convenient excuses to avoid work (Harrington et al., 2012) or to be complaints about being given too much work, or "just" being rudely spoken to (Hutchinson, 2016).

Perhaps, the most telling example of the devaluing of bullying is the noting, by targets across many studies, that the perpetrator is not apparently reprimanded or does not experience any punishment, even in cases where an investigation found in favour of the target. This is particularly distressing for targets (Catley et al., 2016) who can interpret this as a minimising of their pain and distress. In the example below, the interviewee refers to a very public situation in the organisation after which the perpetrator remained in a senior post:

They have this Dignity at Work Policy and they have a poster up on the wall but I mean a lot of us kind of think that's a bit of a joke because they clearly were not taking it seriously, particularly with that individual that was there, you know it was kind of well- known about the bullying. A lot of people felt you know that wasn't ... basically they do not take them seriously. They do things because they have to do or by legally or they've signed up to something. Oh yeah but in reality they do not, I do not think they take them seriously at all (Peggy, E).

\section{Death by discussion; delaying and prevaricating}

There is evidence in the literature of prevaricating and delaying tactics, practiced deliberately at times, e.g. investigations that extend up to four years (Shallcross et al., 2013). However, not all prevarication has fully sinister motives. It can be due to a more general discomfort with or unwillingness to address the problem. Organisations often move the problem around, rather than deal with it, trying to contain it and dissuade targets from taking action (Klein and Martin, 2011). Woodrow and Guest in their study of HRMs in the National Health Service (NHS) found evidence of deliberate delays in the processing of complaints by managers, resulting in targets feeling unsupported and therefore in a worsening situation (Woodrow and Guest, 2014). There are also examples of passing responsibility back and forth between management and $\mathrm{HR}$, or between $\mathrm{HR}$ and the target, which is a form of prevarication. Beirne and Hunter, drawing on two case studies of anti-bullying initiatives, found evidence of senior management backsliding and leaving $\mathrm{HR}$ isolated in their attempts to deal with their bullying problems (Beirne and Hunter, 2012). We found tension between line managers and HR in one organisation (Hodgins et al., 2018); only one of the management participants appeared to accept that they had a responsibility for managing how bullying was resolved in his organisation, others considered it to be HR's problem, while participants from HR were clear that their role was simply to provide the policy or direct managers to the policy, but that managers were to implement it. In organisation E, a member of HR explicitly drew attention to the need to remind employees of their responsibility to take ownership of the problem, as outlined earlier. Managers, for their part, are often unwilling to "have the difficult conversation". We found references to managers who just did not want to know about these problems or who marked time, hoping problems would somehow resolve themselves:

I think they just sort of, step back a bit, someone else's problem. If we leave it long enough, it'll go away (Vanessa, D).

Power and inaction 
IJWHM 13,3

\section{0}

Thirlwall also found evidence of delays, which illustrate the passive exercise of second face power:

Passive rebuffs usually occurred when interviewees were unable to get responses to their complaints from their manager or HR. For example, Felix explained how difficult it was to contact his HR manager, stating, "We send e-mails to make appointments and there's no way you can see the Human Resource Manager". Similarly, Uma's attempts to resolve problems with her line manager were unsuccessful because he did not respond to her concerns, she said: "I sent very strong letters, but they just did not seem to really go anywhere. He'd fob it off [and say] 'Oh I'll think about it.' You know, that kind of thing, 'I'll get back to you later' but he did not" (Thirlwall, 2015) (p. 152).

\section{Invisible power in the organisation}

A third dimension or face of power is described by Lukes as latent or invisible power. This is defined as the exercise of power to implant in people's minds interests that are contrary to their own and is seen to be the most insidious exercise of power (Sadan, 2004). There will be no conflict or challenge to power because the powerful have managed to make the powerless accept their powerlessness uncritically and adopt the agenda of the powerful as their own and even as natural and good. Therefore, it is hard to recognise, and when present, indicates extreme bias in the system. In relation to workplace bullying, this exercise of power would be exemplified by targets uncritically accepting bullying and internalising the negative messages or characterisations communicated to them by the bully (e.g. incompetent, stupid, worthless) or by the organisation (troublemaker, whinger, weak). Gail, from organisation B grapples with this in her description of bullying:

... .am. ...kind of (...) it's kind of a way of putting them down....it's hard to describe and it sounds quite petty... and I think if it's happening to people themselves they may feel it could look paranoid. ...I've personally experienced it very recently with the same person and I felt. . .(stops to take a breath). . . and again you can sound exceedingly paranoid. ...

Unsurprisingly, it is hard to find many examples of this. If power is "successfully" exercised in this way, targets actually are unlikely to respond to invitations to participate in studies on bullying. This possibility is raised by McKay (2014), in her suggestion that third-dimensional power explains why some targets leave; a target perceives that they no longer fit in the organisation, rather than the target or the organisation addressing the behaviour of a more powerful employee, or itself as the agency.

Gaventa's theory of power and powerlessness, based on the studies of an extremely impoverished and disenfranchised community in the Appalachian Valley, traces the process of social change, allowing that any one dimension of power is not absolute, but that the quiescent, at one point bowed under by their powerlessness, come to realise there are alternatives to their position and then come to challenge the social order itself. So, even where power is exercised in its third and hidden face, the "powerless", in this context, targets (who we argue feel powerless in the face of bullying rather than powerless in the wider societal sense) can come to realise this as part of a process, leading to challenge power. In this way, the observations that targets move from an initial questioning of themselves, to a questioning of the organisation, we argue, is evidence of the exercise of invisible power before power becomes visible.

The difficulty targets have in identifying bullying or their reluctance to name it bullying in the early stages is noted in many studies (e.g. Healy-Cullen, 2017; Hodgins and Mannix McNamara, 2017; Karatuna, 2015; Lewis, 2004; 2006a, b; Lutgen-Sandvik, 2008). Anna from organization A for example debated whether her experience of her boss was one of bullying or whether it was too petty:

... she's the type of person that is always out for herself and would, you know, terribly petty stuff, in some ways, would always take holidays at the busiest time of year, you know, would get the holiday 
chart in January-well actually, she'd probably get it the previous September, and keep it in her office, and get everything she wanted up before anybody else would get a go at it, you know, the really sort of petty stuff that we women will do to other women (laughs)...

However, Anna arrived at this realisation following a number of incidents with her perpetrator and the effect it was having on her. She saw how it can be easy to "gloss over" the power plays inherent in bullying:

I used to like, I used to walk past there like this. . (Shakes body) (. . .) and do you know the way your stomach starts lurching, and you just think Oh my God. Now, I can actually go into the building now, still not completely comfortable but, you know there's always that thing that I'm going to meet her. It's a huge amount of power for her to hold-but the funny thing is, it's not just over me she's had that power, I know of at least 2 other people, who have left that office because of the same thing. So, yeah, that's kind of glossing over the actual, that's it in a nutshell.

This face of power clearly requires further exploration in the context of workplace bullying. Given its hidden nature, post-positivist methods such as those found in the tradition of socioanalysis (e.g. Long, 2013) may be important in surfacing invisible power, as yet not generally applied in workplace bullying research.

\section{Discussion}

In this paper, we explore the nature of organizational response to workplace bullying through the lens of the power theory. The literature on workplace bullying is consistent in the finding that organizational response is poor, and that despite 30 years of research, we know very little about how to handle and prevent workplace bullying (Nielsen and Einarsen, 2018). This paper has presented a critical analysis of power relations in organisations, specifically pointing to a disconnect between the devising of policy, which is based on a one-dimensional approach to power, and the implementation of policy, which is better explained by the secondand third-dimension theories and which offer an understanding of power that is both restrictive and sinister (Bacharach and Baratz, 1962).

That power is relevant to workplace bullying has been apparent since the work of Brodsky in 1976 and Einarsen's early work (e.g. Einarsen and Skogstad, 1996). An imbalance of power between the target and the perpetrator features in most definitions, intended to capture the forcing of the will of a more powerful employee on another, either as a result of an escalated conflict through aggressive personal attack or influencing the workload or resources of the target. While an abuse of hierarchical power is perhaps the most typical expression of power, it is by no means the only one; perpetrators can exercise emotional or social power over targets, in some cases, their manager (see e.g. Patterson et al., 2018) or their membership of a minority group (Bachmann and Gooch, 2017; Hodgins et al., 2018). We contend that these agency-based constructions of workplace bullying are underpinned by a one-dimensional understanding of power, as are the policies and procedures drawn up to address it. More advanced explorations of the role of power can be found in Hutchinson et al.'s application of Clegg's circuits of power, McKay's analysis of bullying in the Royal Canadian Mounted Police force (McKay, 2014), McNamara's analysis of power as contested terrain in workplace bullying (Mannix McNamara et al., 2017), D'Cruz and Noronha's work on depersonalised bullying and Liefooghe and MacDavey's notion of the pathologised organisation, all of which explore how oppressive power structures are a form of bullying. These represent an increasing appreciation of the power, subjectivity and context in the study of bullying and signpost the need to embrace postpositivism (D'Cruz et al., 2018), perhaps especially critical management theory, to provide a more complete understanding of the phenomenon.

Post-positivist perspectives offer a more nuanced and realistic view of how power is relevant to the enactment of bullying, and our work builds on this perspective; the organisational response to the raising of bullying issues by individual employees as an

Power and inaction 
IJWHM 13,3

exercise of power. We have argued that workplace bullying is fraught with power issues. They underpin, overarch and hem in bullying in a way that could well be described as Byzantine and brings to mind Foucault's assertion that "power is everywhere" (PowerCube, 2011).

The very context of organisational life contributes to the existence and preservation of bullying and, indeed, other forms of ill-treatment (Mannix McNamara et al., 2017). Power is the currency in organisations that is required to meet productivity and service goals, yet it employed and experienced in a myriad other ways. When organisations fail to protect employees from the micro-politics of organisational life, and the abuse of power via organisational practices, they are in effect exercising the second dimension or face of power (Bacharach and Baratz, 1962), the power to decide what issues are to be decided upon and to frame or define these issues. The exercise of second-dimension power takes many forms, and we have explored examples of these in our own work and also in the literature. It is evident that workplace bullying, both the enactment and the response to it, is an organisational problem, deeply embedded within the organizational processes and practices and will not be addressed effectively without recognition of this fact. We concur with Klein and Martin that organisations assume an attitude of neutrality and ignore the obvious power disparities between parties in bullying disputes, and as a result, fail to address them appropriately (Klein and Martin, 2011).

So, how do we propose organisations should proceed? We acknowledge that it would be useful to identify examples of really good practice in relation to workplace bullying and explore, from a critical theory perspective, how have such organisations managed to balance the traditional exercise of "power over" and the need to protect workers from this abuse of power, both at an individual and organisational level. We are not aware of examples of organisations where bullying has been effectively managed and even prevented. That is not to say that such organisations do not exist, but the literature does not typically offer up such cases, perhaps because the nature of research into organisational behaviour is that it usually, perhaps essentially, has to focus on "bad things, not good", as these are what must change to improve health and well-being (Baumeister CHECK). We advocate a focus on prevention, a comprehensive approach and a fundamental value-clarification piece is what is required to fully protect workers from bullying and, indeed, possibly other forms of abuse.

To afford the best protection to employees, clear statements in the form of an antibullying policy, proscribing bullying and harassment are needed, or else matters are dealt with on a case-by-case basis, rather than systematically and consistently (Duffy, 2009). However, as we have demonstrated, anti-bullying policies are underpinned by a simplistic one-dimensional understanding of power, and are therefore reactive, falling far short of prevention. Indeed, bullying has to happen before it can be addressed. Based on the analysis here, organisations need to also take a preventative approach. We have argued that once the target of bullying invokes the anti-bullying policy, a lot has already happened. Given the recursive nature of relations in workplaces, both individuals, processes and relationships have already been damaged. For some, there may be no road back. An anti-bullying policy is not a preventative intervention. Most are not even aware of their policy until, as much of data have shown, it is too late. Given the demonstrated success of the Civility, Respect, and Engagement in the Workplace (CREW) intervention, which has been shown to effectively reduce incivility and improve civility (Leitrer, etc.), it is surprising that there are so few published examples of the implementation of this intervention. Implementation of this intervention, extended to measure and address bullying, is one way forward. Although the intervention focuses on behaviour, it also includes preparatory work engaging organisation leaders and management, building a learning community of leaders and facilitators, training facilitators and communicating management buy-in to employees. While a structured programme guides the weekly workshops, the experiences and needs of individual groups also dictate choice of exercise, thus responding to the unique situations of 
work groups. The focus is on building positive, civil behaviours, respect, cooperation and conflict resolution.

While creating a positive working environment has long been advocated to counter illtreatment in addition to a number of other negative workplace situations, it is somewhat vague and elusive. We argue that an approach that combines both primary, secondary and tertiary prevention is essential. The success of the whole school approach in relation to school bullying clearly points to the potential in a whole organisation approach. The whole school projects employee as a multi-component model, addressing bullying at several levels in the school and including interventions that improve the overall environment as well as personal skills. Norwegian schools, where the intervention was first devised, have consistently reported very positive results; a reduction of up to $50 \%$ in bully/victim problems and an improved social climate (Olweus, 2003). Positive, although more modest results have been reported from interventions in other countries. While there are important differences between school and workplace bullying, the success of these programmes is noteworthy and the idea of a whole organisation approach is consistent with research on organisational, system-level factors and their role as determinants of workplace bullying. The opportunity to explore how this could be appropriated by workplace health promotion specialists has yet to be grasped, but is clearly a way forward.

What these interventions have in common is that they afford the opportunity to consider or reconsider core values. It is essential to acknowledge the "power and politics" context of workplace is a fundamental factor in bullying. Power needs to be exercised in work organisations, but appropriate protections need to be in place to prevent the abuse of power. Mary Parker Follett is reputed to have said "I do not think we shall ever get rid of "powerover', I do think we should try to reduce it", and this could be a starting point for a comprehensive preventative approach (Eylon, 1998). The tension between the use of power "legitimately" to achieve organisational goals and the way in which effectively affords permission to pressurise, ill-treat and, in some cases, ultimately, bully workers needs to be addressed, and this, we argue, requires a fundamental shift in thinking. As such, the antibullying policy and how it is written or where it can be found is not the place to start. The value base of the organisation is the place to start. Abusive power can only be moderated by fostering norms and values about the careful use of power (Vredenburgh and Brender, 1998). Klein and Martin's thoughtful analysis of workplace bullying reminds us of how it has been necessary with regard to domestic violence to move away from the assumed equivalence between parties and allow that one party has more power in a patriarchal society than the other. They advocate that in the same way, to better protect workers from bullying, the application of an ethical framework for assigning accountability that incorporates the known power differences between individuals or groups is needed (Klein and Martin, 2011). Similarly, institutional abuse has not been served well by analysis of the specific behaviours or factors such as training and stressful conditions, but it is acknowledged that the power of certain institutions within society and individuals within those institutions is the root cause of abuse. A useful starting point for consideration of core values would be to introduce the concept of "abuse of power". Do not call it bullying, call it an abuse of power. This would have the added advantage of embracing sexual harassment and other forms of ill-treatment and would help in acknowledging the source of the problem and signposting the way forward. In moving from a positivist to a post-positivist paradigm, we could effectively move from a discourse of behaviour to a discourse of power, and until that occurs, we may continue to find ourselves surrounded by inaction.

\section{Conclusion}

Workplace bullying is problematic for organisations at several levels. The paper has advocated a realistic assessment of the role of both individual and organisational power in the 
IJWHM 13,3

creation and maintenance of the problem. Such an approach moves away from the specific practice of identifying "bullying", which typically engages targets and perpetrators in a dance that is really just around the edges (Sullivan, 2008) of a larger problem; a culture that permits the abuse of power and ill-treatment of workers, in both practices and through organisational politics. We need to find ways of building a supportive working environment within the context of a power-based, production-focused setting, where benign practices, favourable attitudes to workers and, hence, positive behaviours are fostered and facilitated, but the dangers of power abuse are clearly and openly acknowledged and called out.

\section{Notes}

1. In summary, the first study was a mixed-methods study incorporating a survey and 20 interviews across three large organisations that aimed to explore workers' experiences of organisational response to workplace bullying. A generic qualitative approach was employed as per Kahlke's recommendation (Kahlke, 2014).The latter two studies explored the lived experiences of workplace ill-treatment and bullying of staff in the higher education sector, with a focus on organizational response, employing a qualitative interpretative phenomenological research design. Using nonrandom, purposive sampling strategies, 20 self-selecting participants from three of the seven universities in the Republic of Ireland were interviewed in person. Data were analysed thematically employing the Pietkiewicz and Smith's (2012) model. The 2017 study reported on nine administrative staff, and the (in press) study on the remaining 11 academic staff.

2. In some studies, fixed choice options are given, e.g. trade unions, personnel and others are more general, e.g. "someone in authority". Respondents can usually check a number of options.

3. For a comprehensive discussion on power theory, see Sadan (2004) or Clegg et al. (2005).

4. The actual policies in organisations studied cannot be presented to protect identity of the organisations.

5. Here and throughout, names are pseudonyms. Letter denotes the organization (A-F).

\section{References}

Bacharach, S.B. and Baratz, M.S. (1962), "The two faces of power”, American Political Science Review, Vol. 56, pp. 947-952.

Bachmann, C. and Gooch, B. (2017), "LGBT in Britian”, Work Report, Stonewall, London.

Balducci, C., Fraccaroli, F. and Schaufeli, W.B. (2011), "Workplace bullying and its relation with work characteristics, personality, and post-traumatic stress symptoms: an integrated model", Anxiety, Stress and Coping, Vol. 24 No. 5, pp. 499-513, doi: 10.1080/10615806.2011.555533.

Beale, D. and Hoel, H. (2011), "Workplace bullying and the employment relationship: exploring questions of prevention, control and context”, Work, Employment and Society, Vol. 25 No. 1, pp. 5-18, doi: 10.1177/0950017010389228.

Beirne, M. and Hunter, P. (2012), "Workplace Bullying and challenege of pre-emptive managment", Personnel Review, Vol. 42 No. 5, pp. 595-612.

Bentley, T.A., Catley, B., Cooper-Thomas, H., Gardner, D., O’Driscoll, M.P., Dale, A. and Trenberth, L. (2012), "Perceptions of workplace bullying in the New Zealand travel industry: prevalenceand management strategies", Tourism Management, Vol. 33, pp. 351-360.

Bloisi, W. and Hoel, H. (2010), "The Great HR cover-up: responding to bulllying and abuse in commercial kitchens", Paper presented at the 7th International Conference on Workplace Bullying and Harassment, Glamorgan.

Bryant, M., Buttigieg, D. and Hanley, G. (2009), "Poor bullying prevention and employee health: some implications", International Journal of Workplace Health Management, Vol. 2 No. 1, pp. 48-62, doi: 10.1108/17538350910946009. 
Cambell, M., Fitzpatrick, R., Haines, A., Kinmoth, A., Sandercock, P., Spiegelhalter, D. and Tyrer, P. (2000), "Framework for design and evaluation of complex Interventions", BMJ, Vol. 321 No. 694.

Caponecchia, C. and Wyatt, A. (2011), Preventing Workplace Bullying. An Evidence-Based Guide for Managers and Employees, Allen and Unwin, London.

Catley, B., Bentley, T., Forsyth, D., Cooper-Thomas, H., Gardner, D., O’Driscoll, M. and Trenberth, L. (2013), "Managing workplace bullying in New Zealand: perspectives from occupationalhealth and safety practitioners", Journal of Managment and Organisation, Vol. 19 No. 5, pp. 598-612.

Catley, B., Blackwood, K., Forsyth, D. and Tappin, D. (2016), “Workplace bullying complaints: lessons for 'ggod HR Practice”, Personel Review, Vol. 46 No. 1, pp. 100-114.

Cicerali, L.K. and Cicerali, E.E. (2015), "A qualitative study on how Swedish organizations deal with workplace bullying”, Nordic Psychology, Vol. 68 No. 2, pp. 87-99.

Clegg, S., Kornberger, M. and Pitsis, T. (2005), Managing and Organisations. An Introduction to Theory and Practice, Sage, London.

Coetzee, M. and VanDyk, J. (2018), "Workplace bullying and turnover intention: exploring work engagement as a potential mediator", Psychological Reports, Vol. 121 No. 2, pp. 375-392.

Connolly, U. and Quinlavan, S. (2017), "Accessing justice in cases of occupational bullying in Ireland", The Irish Community Development Law Journal, Vol. 5 No. 1.

Cowan, R. (2011), “Yes, we have an anti-bullying policy, but'... HR professionals' understandinsg and experiences with workplace bullying", Communication Studies, Vol. 62 No. 3, pp. 307-327.

Crimp, H. (2017), Effective Prevention Of Public Sector Workplace Bullying: Are We There Yet, Victoria Centre Labour Employment and Work, Wellington.

D'Cruz, P. and Norohona, E. (2009), "Experiencing depersonalised bullying: a study of Indian callcentre agents", Work Organisation, Labour and Globalisation, Vol. 3 No. 1, pp. 26-46, doi: 10. 13169/workorgalaboglob.3.1.0026.

D'Cruz, Noroha and Lutgen-Sandvik (2018), "Power, subjectivity and context in workplace bullying, emotional abuse and harassment: insights from post positivism", Qualitative Research in Organizations and Management, Vol. 13 No. 1, pp. 2-9.

de Wet, C. (2014), "Educators' understanding of workplace bullying", South African Journal of Education, Vol. 34 No. 1, pp. 1-16.

De Conto Garbin, A. and Fischer, F.M. (2012), "Representations of workplace psychological harassment in print news media”, Review Saude Publica, Vol. 46 No. 3, pp. 1-7.

Duffy, M. (2009), "Preventing workplace mobbing and bullying with effective organisational consultation policies and legislation”, Counsulting Psychology Journal, Vol. 61 No. 3, pp. 242-262.

Dykema, L.L. (1985), "Gaventa's theory of power and powerlessness: application to nursing", Occupational Health Nursing, September.

Einarsen, S. and Skogstad, A. (1996), "Bullying at work: epidemiological findings in public and private organizations", European Journal of Work and Organizational Psychology, Vol. 5 No. 2, pp. 185-201, doi: 10.1080/13594329608414854.

Einarsen, S., Hoel, H., Zapf, D. and L., C.C. (2011), "The concept of bullying and harassment at work: the european tradition", in Einarsen, S., Hoel, H., Zapf, D. and Cooper, C.L. (Eds), Bullying and Harassment in the Workplace, Taylor and Francis, London, pp. 3-40.

Evesson, J. and Oxenbridge, S. (2015), Seeking Better Solutions: Tackling Bullying And Ill-Treatment In Britian's Workplaces, ACAS, London.

Eylon, D. (1998), "Understanding empowerment and resolving its paradox: lessons from mary parker Follett", Journal of Management History, Vol. 4 No. 1, pp. 16-28.

Ferris, P. (2004), "A preliminary typology of organisational response to allegations of workplace bullying; see no evil, hear no eviel, speak no evil”, British Journal of Guidance and Counselling, Vol. 32 No. 3, pp. 389-395.

Power and inaction 
IJWHM 13,3

286

Gaventa, J. (1980), Power and Powerlessness. Quiescence and Rebellion in an Appalachian Valley, University of Illinois Press, Chicago.

Georgo, M. (2017), A Qualitative Analysis of the Depiction of Workplace Bullying in Hollywood Films, (Ph.D), Nova South Eastern University, Davie, FL.

Giaccone, M., Di Nunzio, D. and Vargas, O. (2015), Violence and Harassment In European Workplaces; Causes, Impacts And Policies, Dublin.

Giorgi, G., Mancuso, S., Fiz Perez, F., Castellio, D., Antonio, A. and Mucci, N. (2015), "Bullying among nurses and its relationship with burnout and organizational climate", Inernatuional Journal of Nursing Practice, Vol. 22 No. 2, pp. 160-178, doi: 10.1111/ijn.12376.

Harrington, S., Rayner, C. and Warren, S. (2012), "Too hot to handle? Trust and human resource practitioners' implementation of anti-bullying policy", Human Resource Management Journal, Vol. 22 No. 4, pp. 392-408.

Harrington, S., Warren, S. and Rayner, C. (2015), "Human Resource Management practitioners' responses to workplace bullying: cycles of symbolic violence”, Organization, Vol. 22 No. 3, pp. 368-389.

Hauge, L.J., Skogstad, A. and Einarsen, S. (2010), "The relative impact of workplace bullying as a social stressor at work", Scandinavian Journal of Psychology, Vol. 51 No. 5, pp. 426-433, doi: 10. 1111/j.1467-9450.2010.00813.x.

Hayman, M. (2015), Gender And Gender Minority Differences In Workplace Bullying Within New Zealand Organisations, MA Applied Psychology, University of Waikato, available at: https:// researchcommons.waikato.ac.nz/bitstream/handle/10289/9502/thesis.pdf?sequence $=3 \&$ isAllowed $=\mathrm{y}$.

Health and Safety Authority (2007), "Code of practice on the prevention and resolution of bullying at work", Dublin, available at: http://www.hsa.ie/eng/Publications_and_Forms/Publications/ Occupational_Health/CoP_Bullying.pdf.

Healy-Cullen, S. (2017), "Is workplace bullying in the eye of the beholder", Journal of Mediation and Applied Conflict Analysis, Vol. 4 No. 2, pp. 563-577.

Hockley, C. (2002), "The impact of workplace violence on third party victims: a mental health perspective", in Morrow, L., Verins, I. and Willis, E. (Eds), Mental Health and Work. Issues and Perspectives, Auseinet, Adelaide, The Australian Network for Promotion, Prevention and Early Intervention for Mental Health.

Hodgins, M. (2004), Perceptions of Anti-Bullying Policy and Practice in NUI Galway, Health Promotion Research Centre, National University of Ireland Galway, Galway.

Hodgins, M. and Mannix McNamara, P.M. (2017), "Bullying and incivility in higher education workplaces Micropolitics and the abuse of power", Qualitative Research in Organizations and Management, Vol. 12 No. 3, pp. 190-206, doi: 10.1108/Qrom-03-2017-1508.

Hodgins, M. and Mannix McNamara, P. (2019), “An enlightened environment? Workplace bullying and incivility in Irish higher education", SAGE Open, Oct-Dec, pp. 1-13.

Hodgins, M., Mac Curtain, S. and MannixMcNamara, P. (2014), "Workplace Bullying and Incivility: a systematic review of interventions", International Journal of Workplace Health Management, Vol. 7 No. 1, pp. 54-72.

Hodgins, M., Pursell, L., Hogan, V., Mannix McNamara, P. and MacCurtain, S. (2018), Irish Workplace Behaviour Study, Health Promotion Research Centre, Galway.

Hoel, H. (2013), "Workplace bullying in the United Kingdom”, available at: http://www.jil.go.jp/english/ reports/documents/jilpt-reports/no.12_u.k..pdf.

Hoel, H. and Cooper, C. (2000), Destructive Conflict And Bullying At Work, University of Manchester, Manchester.

Hoel, H. and Einarsen, S. (2010), "Shortcomings of antibullying regulations: the case of Sweden", European Journal of Work and Organizational Psychology, Vol. 19 No. 1, pp. 30-50. 
Hurley, J., Hutchinson, M., Bradbury, J. and Browne, G. (2016), "Nexus between preventive policy inadequacies, workplace bullying, and mental health: qualitative findings from the experiences of Australian public sector employees", International Journal of Mental Health Nursing, Vol. 25 No. 1, pp. 12-18, doi: 10.1111/inm.12190.

Hutchinson, J. (2016), "Rethinking workplace bullying as an employment relations problem", Journal of Industrial Relations, Vol. 54 No. 5, pp. 637-652.

Hutchinson, M. and Hurley, J. (2012), "Exploring leadership capability and emotional intelligence as moderators of workplace bullying", Journal of Nursing Management, Vol. 21 No. 1, pp. 553-562.

Hutchinson, M., Vickers, M., Jackson, D. and Wilkes, L. (2006), "Workplace bullying in nursing: towards a more critical organisational perspective”, Nursing Inquiry, Vol. 13 No. 2, pp. 118-126, doi: 10.1111/j.1440-1800.2006.00314.x.

Hutchinson, M., Vickers, M.H., Jackson, D. and Wilkes, L. (2010), "Bullying as circuits of power", Administrative Theory and Praxis (M.E. Sharpe), Vol. 32 No. 1, pp. 25-47, doi: 10.2753/ATP10841806320102.

Jenkins, M.F. (2011), Workplace Bullying: The Perceptions of the Target, the Alleged Perpetrator and the HR Professional, Doctor of Philosopy, University of Adelaide.

Kahn, A. and Kahn, R. (2012), "Understanding and managing workplace bullying”, Industrial and Commercial Training, Vol. 44 No. 2, pp. 85-89.

Kahlke, R. (2014), "Generic qualitative approaches: pitfalls and benefits of methodological mixology", International Journal of Qualitative Methods, Vol. 13 No. 1, pp. 37-52.

Karatuna, I. (2015), “Targets' coping with workplace bullying: a qualitative study", Qualitative Research in Organizations and Management, Vol. 10 No. 1, pp. 21-37, doi: 10.1108/QROM-092013-1176.

Kearins, K. (1996), "Power in organisational analysis: delineating and contrasting a foucauldian perspective", Electronic Journal of Radical Organisational Theory, Vol. 12 No. 2, pp. 1-24.

Keashly, L. (2010), "A researcher speaks to ombudsmen about workplace bullying”, Journal of the International Ombudsman Association, Vol. 3 No. 2, pp. 10-23.

Keashly, L. and Jagatic, K. (2011), "North American perspectives on hostile behaviours and bullying at work", in Hoel, H., Einarsen, S., Zapf, D. and Cooper, C. (Eds), Bullying and Harassment in the Workplace, Taylor and Francis, London, pp. 41-74.

Keashly, L., Jagatic, K. and Neuman, J.H. (2008), Final Report: Workplace Behavior (Bullying) Project Survey, Wayne State University, Detroit.

Kivimäki, M., Elovainio, M. and Vahtera, J. (2000), "Workplace bullying and sickness absence in hospital stay", Occupational and Environmental Medicine, Vol. 57, pp. 656-660.

Klein, A. and Martin, S. (2011), "Two dilemmas in dealing with workplace bullies - false positives and deliberate deceit", International Journal of Workplace Health Management, Vol. 4 No. 1, pp. 13-32.

Lewis, D. (2004), "Bullying at work: the impact of shame among university and college lecturers", British Journal of Guidance and Counselling, Vol. 32 No. 3, pp. 281-299, doi: 10.1080/ 03069880410001723521.

Lewis, M.A. (2006), "Nurse bullying: organizational considerations in the maintenance and perpetration of health care bullying cultures", Journal of Nursing Management, Vol. 14 No. 1, pp. 52-58, doi: 10.1111/j.1365-2934.2005.00535.x.

Lewis, S.E. (2006), "Recognition of workplace bullying: a qualitative study of women targets in the public sector", Journal of Community and Applied Social Psychology, Vol. 16 No. 2, pp. 119-135, doi: 10.1002/casp.850.

Leymann, H. (1996), "The content and development of mobbing at work”, European Journal of Work and Organisational Psychology, Vol. 5 No. 2, pp. 165-184.

Power and inaction 
IJWHM 13,3

Liefooghe, A.P.D. and MacDavey, K. (2010), "Accounts of workplace bullying: the role of the organisation”, European Journal of Work and Organisational Psychology, Vol. 10 No. 4, pp. 375-392.

Long, S. (2013), Socioanalytic Methods, Karnac books, London.

Lutgen-Sandvik, P. (2008), "Intensive remedial identity work: responses to workplace bullying trauma and stigmatization", Organisation, Vol. 15 No. 1, pp. 97-111.

MacMahon, J., O’Sullivan, M., Murphy, C. and Ryan, L. (2018), “\&Author 3, SSpeaking up or staying silent in bullying situations: the significance of management control", Industrial Relations Journal, Vol. 49 Nos 5-6, pp. 473-491.

Mannix McNamara, P., Fitzpatrick, K., MacCurtain, S. and O’Brien, M. (2017), “Workplace bullying and redress procedures: experiences of teachers in Ireland", Journal of Research in Organsiations and Management, Vol. 13 No. 1, pp. 79-97, doi: 10.1108/QROM-10-2016-1440.

Mayhew, C., McCarthy, P., Chappell, D., Quinlan, M., Barker, M. and Sheehan, M. (2004), "Measuring the extent of impact from occupational violence and bullying of traumatised workers", Employee Responsibilities and Rights Journal, Vol. 16 No. 3, p. 117134.

McCalla-Chen, D. (2000), "Towards an understanding of the concept of non-decision making and its manifestation in the school sector", Educational Management anfd Administration, Vol. 28 No. 1, pp. 33-46.

McCormack, D., Casimir, G., Djurkovic, N. and Yang, L. (2009), "Workplace bullying and intention to leave among schoolteachers in China: the mediating effect of affective commitment", Journal of Applied Social Psychology, Vol. 39 No. 9, pp. 2106-2127, doi: 10.1111/j.1559-1816.2009.00518.x.

McKay, R.B. (2014), "Confronting workplace bullying: agency and structure in the royal canadian mounted police", Administration and Society, Vol. 46 No. 5, pp. 548-572, doi: 10.1177/ 0095399713509245.

Mintzberg, H. (1983), Power in and Around Organisations, Prentice-Hall, New Jersey, NJ.

Namie, G. (2012), "WBI study: attempts to stop bullying at work by targeted workers are ineffective", available at: https://www.workplacebullying.org/effectiveness/.

Namie, G. (2012), "WBI 2012 research summary”, available at: https://www.workplacebullying.org/ wbi-2012-research-summary/.

Namie, G. (2017), “2017 WBI U.S. workplace bullying survey”, available at: http://www. workplacebullying.org.

Niedhammer, I., David, S. and Degionni, S. (2006), “Association between workplace bullying and depressive symptoms in the French working population", Journal of Psychosomatic Research, Vol. 61 No. 2, pp. 251-259.

Nielsen, M.B. and Einarsen, S.V. (2018), "What we know, what we do not know, and what we should and could have known about workplace bullying: an overview of the literature and agenda for future research", Aggression and Violent Behavior, Vol. 42, pp. 71-83, doi: 10.1016/j.avb.2018. 06.007 .

Nielsen, M.B., Matthiesen, S.B. and Einarsen, S. (2009), "The impact of methodological moderators on prevalence rates of workplace bullying. A meta-analysis", Journal of Occupational and Organizational Psychology, Vol. 83 No. 4, pp. 955-979.

Notelaers, G., Einarsen, S., De Witte, H. and Vermunt, J.K. (2006), "Measuring exposure to bullying at work: the validity and advantages of the latent class cluster approach", Work and Stress, Vol. 20 No. 4, pp. 289-302, doi: 10.1080/02678370601071594.

O'Connell, P.J., Calvert, E. and Watson, D. (2007), Bullying The The Workplace: Survey Reports, 2007, ESRI, Dublin.

O’Donnell, S.M. and MacIntosh, J.A. (2016), “Gender and workplace bullying: men's experiences of surviving bullying at work", Qualitative Health Research, Vol. 26 No. 3, pp. 351-366, doi: 10. 1177/1049732314566321. 
O'Higgins, J. and Kiernan, N.G. (2015), Bullying in the Workplace: An Analysis of Cases at the Employment Tribunal under the Unfair Dismissals Acts (1977-2007), Retrieved from ABC, National Anti-bullying Research and Resource Centre, Dublin City University, Dublin.

O’Moore, M. (2000), National Survey On Bullying In The Workplace, Anti Bullying Centre, Dublin.

Olsen, H. (2018), "Why the 'ZERO Tolerance' approach doesn't really work”, available at: https://www. linkedin.com/pulse/why-zero-tolerance-approach-doesnt-really-work-hadyn-olsen/.

Olweus, D. (2003), "Bully/victim problems in the school:basic facts and an effective intervention programme", in Einarsen, S., Hoel, H., Zapf, D. and Cooper, C.L. (Eds), Bullying Emotional Abuse in the Workplace, Taylor and Francis, London.

Patterson, E., Branch, S., Barker, M. and Ramsay, S. (2018), "Playing with power: examinations of types of power used by staff members in workplace bullying - a qualitative interview study", Qualitative Research in Organisations and Management, Vol. 13 No. 1, pp. 32-52.

Pietkiewicz, I. and Smith, J.A. (2012), "Praktycznyprzewodnikinterpretacyjnejanalizyfenomenologic znej w badaniachjakościowych w psychologii. (English TRANSLATION)", Czasopismo Psychologiczne, Vol. 18 No. 20, pp. 361-369.

PowerCube (2011), “Understanding power for social change”, available at: https://www.powercube.net/ an-introduction-to-power-analysis/.

Quine, L. (1999), "Workplace bullying in NHS community trust: staff questionnaire survey”, British Medical Journal, Vol. 318 No. 7178, pp. 228-232.

Rayner, C. (1997), "The incidence of workplace bullying", Journal of Community and Applied Social Psychology, Vol. 7, pp. 199-207.

Rayner, C. and McIvor, K. (2008), Research Report On Dignity At Work Project, University of Portsmouth, Portsmouth.

Razzaghian, M. and Ghani, U. (2014), "Effect of workplace bullying on turnover intention of faculty members: a case of private sector universities of khyber pakhtunkhwa, Pakistan”, Business and Economic Review, Vol. 6 No. 1, pp. 40-51.

Richards, J. and Daley, H. (2003), "Bullying policy: development, implementation, and monitoring", in Einarsen, S., Hoel, H., Zapf, D. and Cooper, C.L. (Eds), Bullying and Emotional Abuse in the Workplace: International Perspectives in Research and Practice, Taylor and Francis, London, pp. 127-144.

Rockett, P., Fan, S.K., Dwyer, R.J. and Foy, T. (2017), "A human resource management perspective of workplace bullying", Journal of Agression, Conflict and Peace Research, Vol. 9 No. 2, pp. 116-127.

Russell, H., Maitre, B., Watson, D. and Fahey, E. (2018), Job Stress Amd Working Conditions, Irealnd In Comparitivve Perspective, ESRI, Dublin.

Sadan, E. (2004), "Empowerment and community planning", available at: http://www.mpow.org/ elisheva-sdan-empowerment.pdf.

Salin, D. (2003), "Ways of explaining workplace bullying: a review of enabling, motivating and precipitating structures and processes in the work environment", Human Relations, Vol. 56 No. 10, pp. 1213-1232.

Salin, D. (2009), "Organisational responses to workplace harassment; an exploratory study", Personnel Review, Vol. 38 No. 1, pp. 26-44.

Salin, D. and Notelaers, G. (2017), "The effect of exposure to bullying on turnover intentions: the role of perceived psychological contract violation and benevolent behaviour", Work and Stress, Vol. 31 No. 4, pp. 355-374.

Schneider, E. and Irastorza, X. (2010), OSH In Figures: Work-Related Musculoskeletal Disorders In The Eu - Facts And Figures, EU-OHSA, Luxembourg.

Shallcross, L., Ramsey, S. and Barker, M. (2013), "Severe workplace conflict: the experience of mobbing”, Negotiation and Conflict Management Research, Vol. 6 No. 3, pp. 191-213. 
IJWHM 13,3

290

Shellie, S. (2008), "Workplace bullying experienced by Massachusetts registered nurses and the relationship to intention to leave the organization", Advances in Nursing Science, Vol. 31 No. 2, pp. E48-E59.

Silvia, P., Arianna, P., Castellini, G., Conway, P.M., Edorado, M., Cassito, M.G. and Giovanna, C. (2010), "Victims of workplace bullying 6 years following examination", Paper presented at the 7th International Conference on Workplace Bullying and Harassment 'Transforming Research, Evidence and Practice', Glamorgan.

Smith, M. (2006), "The present defects of Irish Law regarding workplace bullying and possible solutions", Paper presented at the 'The Way Forward' The fifth International Conference on Bullying and Harassment in the Workplace, Trinity College, Dublin.

Sprigg, C., Martin, A., Niven, K. and Armitage, C. (2010), Unacceptable Behaviour, Health And Wellbeing At Work, A Cross-Lagged Longitudinal Study, IOSH, Leicester.

Sullivan, K. (2008), La Courage De La Verite - The Courage To Tell The Truth And Bullying In The Workplace: A Preliminary Examination.

Sullivan, K. (2010), "Bullying in the Irish workplace: a cause or concern", in Osterman, K. (Ed.), Indirect and Direct Aggression, Peter Lang, Frankfury am main, Berlin, Bern, Bruxelles, Vienna.

Task Force on the Prevention of Workplace Bullying (2001), Dignity At Work, The Challenge Of Workplace Bullying, ESRI, Dublin.

Thirlwall, A. (2015), "Organisational sequestering of workplace bullying: adding insult to injury", Journal of Management and Organization, Vol. 21 No. 2, pp. 145-158, doi: 10.1017/jmo.2014.72.

Tuckey, M., Yiqiong, L., Neall, A.M., Mattiske, J.D., Chen, P.Y. and Dollard, M. (2018), Developing A Workplace Bullying Risk Audit Tool, Final Project Report, University of Southern Australia, Adelaide.

Vega, G. and Comer, D.R. (2005), "Sticks and stones may break your bones, but words can break your spirit", Journal of Business Ethics, Vol. 58 No. 1, pp. 101-109.

Vickers, M. (2012), "A rhetorical portrayal of the sham face of organisational support", Administrative Theory and Praxis, Vol. 34 No. 4, pp. 533-556.

Vredenburgh, D. and Brender, Y. (1998), "The hierarchical abuse of power in work organisataions", Journal of Business Ethics, Vol. 17, pp. 1337-1347.

Woodrow, C. and Guest, D.E. (2014), "When good HR gets bad results: exploring the challenge of HR implementation in the case of workplace bullying", Human Resource Management Journal, Vol. 24 No. 1, pp. 38-56, doi: 10.1111/1748-8583.12021.

Zapf, D., Escartin, J., Einarsen, S., Hoel, H. and Vartia, M. (2011), "Empirical findings on prevalance and risk groups of bullying in the workplace", in S Einarsen, H.H., Zapf, D. and Cooper, C.L. (Eds), Bullying and Harassment in the Workplace, Taylor and Francis, London.

\section{Corresponding author}

Margaret Hodgins can be contacted at: margaret.hodgins@nuigalway.ie

For instructions on how to order reprints of this article, please visit our website:

www.emeraldgrouppublishing.com/licensing/reprints.htm

Or contact us for further details: permissions@emeraldinsight.com 